\title{
Longitudinal connectivity in hydromorphological quality assessments of rivers. The ICF index: A river connectivity index and its application to Catalan rivers
}

\author{
Carolina Solà*1, Marc Ordeix ${ }^{2}$, Quim Pou-Rovira ${ }^{2}$, Núria Sellarès ${ }^{2}$, Aida Queralt ${ }^{3}$, Mònica \\ Bardina $^{1}$, Anna Casamitjana ${ }^{1}$ and Antoni Munné ${ }^{1}$
}

${ }^{1}$ Agència Catalana de l'Aigua, Departament de Territori i Sostenibilitat de la Generalitat de Catalunya. Carrer de Provença, 204-208. 08036 Barcelona, Catalunya.

${ }^{2}$ Centre d'Estudis dels Rius Mediterranis, Museu Industrial del Ter. Passeig del Ter, 2. 08560 Manlleu, Catalunya (cerm@mitmanlleu.org).

${ }^{3}$ United Research Services España, S.L. Carrer d'Urgell, 143, $4^{a}$ planta. 08036 Barcelona, Catalunya

(aidaqueralt@gmail.com).

*Corresponding author: csolao@gencat.cat

Received: 24/3/2010 Accepted: 8/2/2011

\begin{abstract}
Longitudinal connectivity in hydromorphological quality assessments of rivers. The ICF index: A river connectivity index and its application to Catalan rivers

The Water Framework Directive urges assessment of river continuity as an input for the evaluation of hydromorphological quality. The existence of transverse obstacles in river beds has serious ecological consequences because it blocks the natural flow of water, sediments and biota, and this is considered one of the major causes of declines in many continental fish species. The index of river connectivity (ICF, from the Catalan name Index de Connectivitat Fluvial) evaluates obstacle effects on fish movement alone and does not take into account other elements affected by the obstacles. However, it can be used as a complementary element in hydromorphological condition assessments.

The index is based on comparison of obstacle and fish pass (if any) characteristics with the capabilities of the fishes potentially present in the considered river section to overcome the obstacle. In this study, we present a new version of the ICF improved from its earlier version that was tested by different consultants and research centres for several obstacles from 2006 to 2009. The new version of the ICF is divided into three blocks that encompass assessment of (1) the obstacle and (2) the fish pass (if any) as well as (3) the estimation of certain modulators. Finally, the ICF classifies connectivity into five levels from very good to bad depending on the degree of permeability for different fish groups. This new version of the ICF has been tested for 101 transverse obstacles in rivers in Catalonia (NE Iberian Peninsula) both with and without fish passes, obtaining representation of the five expected quality levels (from very good to bad), and it is considered coherent with the real permeability of the obstacles. Its ease of application compared to in situ measurements of fish movements and the detailed information recorded by the index make it a very useful tool for the diagnosis of the longitudinal connectivity of rivers and for guiding measures for hydromorphological quality improvement.
\end{abstract}

Key words: Fish migration, transversal barriers, fish passes, hydromorphological assessment, Water Framework Directive, connectivity.

\section{RESUMEN}

La conectividad fluvial en la evaluación de las condiciones hidromorfológicas de los ríos. El índice ICF: Un índice de conectividad fluvial y su aplicación a los ríos catalanes

La Directiva Marco del Agua define que para evaluar la calidad hidromorfologica de los rios hay que valorar, entre otros factores, la continuidad fluvial. La existencia de obstáculos transversales al cauce fluvial tiene importantes consecuencias ecológicas, y se considera una de las causas principales del declive de muchas especies continentales de peces. Por ello se ha diseñado el Índice de Conectividad Fluvial (ICF), que aunque sólo considera los peces y no otros compartimentos 
afectados (agua y sedimentos), puede ser utilizado como parte integrante del protocolo completo de evaluación de la calidad hidromorfológica de los ríos en Catalunya (protocolo HIDRI).

El ICF se basa en la comparación de las características de un determinado obstáculo y de los dispositivos de paso para peces (si dispone de ellos) con las capacidades para superarlo de las distintas especies de peces autóctonos potencialmente presentes en el tramo. En este estudio se presenta una versión mejorada del ICF, que ha sido probada por distintos equipos de consultorías y centros de investigación entre 2006 y 2009. La nueva versión consta de tres grandes bloques que incluyen la evaluación de (1) el obstáculo, (2) el o los dispositivos de paso de peces, en caso que los haya, y (3) la estimación de distintos moduladores. Finalmente, el ICF clasifica el nivel de conectividad en cinco rangos, de muy bueno a malo, en función del grado de franqueabilidad para los distintos grupos de especies potencialmente presentes en el tramo. La nueva versión del ICF ha sido aplicada en 101 obstáculos transversales de distintos ríos de Catalunya (NE de la península Ibérica), con y sin dispositivos de paso para peces. En los resultados se encuentran representados los cinco rangos de calidad posibles (desde muy bueno a malo), resultados que se consideran coherentes con la permeabilidad real del obstáculo. Su fácil aplicación, en comparación con la evaluación in situ de los movimientos de los peces, así como los detalles de la información recogida en las hojas de campo, sugieren que el ICF es una buena herramienta tanto para diagnosticar la conectividad longitudinal como para orientar las medidas a tomar para la mejora de la calidad hidromorfológica.

Palabras clave: Migración de peces, barreras transversales, dispositivos de paso para peces, calidad hidromorfológica, Directiva Marco del Agua, conectividad.

\section{INTRODUCTION}

The existence of transverse obstacles in rivers preventing water, sediments and fauna from flowing has important ecological consequences because the hydromorphological and biological conditions of the ecosystem are directly or indirectly affected (Cowx \& Welcomme, 1998). The total or partial retention of water and sediments leads to loss or alteration of water habitats upstream and downstream the obstacle (Larinier, 2001), and it has effects on the distribution, abundance and survival of species present. These obstacles represent barriers to the migration of many aquatic and semi-aquatic species, and thus, they have direct effects on population biology, such as causing local extinctions due to a lack of dispersion and recolonisation, genetic isolation, impediments to reproduction, and non-accessibility to feeding resources and shelter areas (Lucas \& Baras, 2001). Poor river connectivity is considered one of the main reasons for declines in many continental Iberian fish species (Sostoa, 1990; Elvira et al., 1998a; Aparicio et al., 2000; Encina et al., 2001; Lucas \& Baras, 2001; Casals, 2005; Santo, 2005), European species (Bruslé \& Quignard, 2001; Larinier, 2001; Kroes et al., 2006) and species from other continents (Jungwirth et al., 1998; Thorncraft \& Harris, 2000; Marmulla \& Welcomme, 2002). Although some species can complete their life cycle in highly fragmented rivers when they have free space, they carry out much longer migrations (Geeraerts et al., 2007).

Conservation of fish diversity is one of the most critical issues with respect to preserving global European biodiversity (Zitek et al., 2008). This issue is gaining prominence not only because of the declines of some commercial fish species, such as eels (Anguilla anguilla), but also because of the increasing environmental sensitivity of society related to improving the ecological quality of ecosystems in general and the mobility of aquatic fauna in particular. Reestablishment of river connectivity has also become a legal requirement under the Water Framework Directive (WFD, 2000/60/EC; EC, 2000) and the European Plan for Eel Recovery (Regulation 1100/2007; EC, 2007), and it is extremely important for the maintenance of the conservation status of many freshwater species included in the nature 2000 network (Habitats Directive 92/43/CEE; EC, 1992).

Recovery of river connectivity by restoring the different components affected by a specific obstacle (water, sediments and biota) can be 
achieved by the total or partial demolition of the obstacle in some cases (Marmulla \& Welcomme, 2002; Amstrong et al., 2004; Kroes et al., 2006). However, this type of solution can be difficult to accomplish because many times the obstacles present in a river play an important role for human society, such as weirs to generate hydroelectric power, extraction to provide water supplies, or other elements considered to be associated with cultural heritage. In such cases, improvement of river connectivity is usually centred on aquatic fauna, and it consists of putting into place a device or solution (hereafter, fish passes) to assist the fish fauna in travelling upstream.

Installation of a fish pass at an obstacle does not guarantee the effective re-establishment of river connectivity for fishes because its functionality depends on fish pass construction criteria, its maintenance and management, and its suitability for the fauna and the type of river where it is installed. Evaluation of fish pass effectiveness can be conducted by directly or indirectly estimating the permeability rate of every fish species using different methodologies (Lucas \& Baras, 2001; Travade \& Larinier, 2002; Marmulla \& Welcomme, 2002; Roni, 2005; Santo, 2005; Ordeix et al., 2011). These techniques require fish population surveys and application of marking and recapture methods in some cases. Additionally, they depend on previous knowledge regarding species phenology because fish movements in rivers are usually concentrated in particular seasons (Rodríguez-Ruiz \& Granado-Lorencio, 2006), and the application of a specific method depends on many other factors (Lucas \& Baras, 2001). These methods are relatively expensive and require long-term monitoring, which makes their application to an entire catchment very difficult.

Longitudinal connectivity has been poorly studied on the Iberian Peninsula. For example, in the Catalan region, the few existing studies have evaluated only a small fraction of the existing obstacles (Elvira et al., 1998a; Elvira et al., 1998b) or have dealt with very specific areas (Catalán et al., 1997; Ordeix et al., 2009a). However, a recent study identified over a thousand infrastructure projects in Catalonia that could alter longitudinal connectivity in these rivers, which were mainly large dams (over $15 \mathrm{~m}$ in height), weirs (under $15 \mathrm{~m}$ ), crossings, gauging stations, bed sills and road and railway bridge pillars, (ACA, 2005; Ordeix et al., 2006; Ordeix et al., 2011), and only 78 fish passes were found among all of these obstacles.

A preliminary step in prioritising the restoration of river longitudinal connectivity is evaluation of the degree of impact of structures that might generate discontinuity and the efficiency of existing fish passes. Furthermore, this is also a requirement of the WFD, as it specifies that river connectivity is one of the hydromorphological elements that must be evaluated within an ecological status assessment. However, obtaining estimations of fish permeability rates through specifically designed surveys for each individual obstacle found in a water agency domain is prohibitive in terms of cost and effort, especially if this must be repeated periodically. Moreover, it is also important to take into account that fish species can encounter many obstacles during migration, and all of them must be evaluated. In this context, the development of a simple indicator allowing estimation of obstacle permeability (with or without fish passes) without requiring biological samples is quite urgently needed.

Although different hydromorphological quality indices exist (Boon et al., 1997 \& 1998; Raven et al., 1998; Agences de l'Eau, 2002; Fleischhacker \& Hern, 2002; Pedersen \& Baattrup-Pedersen, 2003; Buffagni et al., 2005; CEN, 2010), river longitudinal connectivity has always been poorly assessed. Thus, the ICF (from the Catalan name Index de Connectivitat Fluvial-river connectivity index) was designed as part of a procedure to assess the hydromorphological quality of Catalan rivers (HIDRI protocol-ACA, 2006). Application of this index by several consultancies and research centres (Ferrer et al., 2009; Ordeix et al., 2006; Rocaspana et al., 2009) revealed the existence of deficiencies that yielded a final result that did not coincide with real longitudinal connectivity evaluated independently. Therefore, the present study aims to present a new version of the ICF capable of correcting the identified deficiencies. We will compare results obtained using both the new and old versions of the index for 101 obstacles in different Catalan river catchments and 
comment on the application of the new ICF version for the diagnosis and improvement of hydromorphological quality in rivers.

\section{METHODOLOGY}

\section{Basis of the ICF}

The aim of the ICF is to carry out a preliminary evaluation of the permeability of river longitudinal obstacles and of fish passes (if any) associated with those obstacles. It must be born in mind that the ICF is not a method that assesses real obstacle permeability but instead makes an approximation through a simple but strict methodology to estimate the chance of fish fauna being altered, especially upstream. The ICF is based on comparison between the physical characteristics of the obstacle and the fish pass (if any) and the swimming and/or jumping skills related to travelling upstream of the potential fish fauna present in the river section evaluated. Then, the index discriminates each infrastructure based on the chance it can be crossed by all species, only by some species, or by no species. Thus, the application of the ICF could be complementary to in situ assessment of fish permeability by means of fish capture, marking and recapture, or other fish survey methods. Moreover, the ICF is not designed to assess how the obstacle alters longitudinal connectivity regarding sediment or water movement, which must be evaluated by other specific methods, such as compliance with the environmental flow regime (ACA, 2006) or indicators of hydrological alteration (Ricther et al., 1996; Martínez \& Fernández, 2006; Martínez \& Fernández, 2007) of water. It is also important to highlight that the index evaluates the degree of connectivity based on the hydrological conditions of the time at which the inspection is performed, which should be representative of the normal conditions of the evaluated river section.

To apply the ICF, a series of steps must be followed: (1) the potential fish fauna in the river section must be determined; (2) the fish fauna must be classified according to the ability to overcome obstacles in some of the proposed groups
(Table 1); (3) the obstacle and fish pass (if any) will be classified and different characteristics of these structures will be measured; (4) the capacity of potentially present fish to overcome obstacles will be contrasted with the characteristics measured in the field, which will provide a first indication of which fish groups would be able to overcome the obstacle; and (5) some final modulators will be checked to obtain the final value of the ICF.

\section{Ichthyofauna classification}

The capacity of river fishes to overcome transverse obstacles depends on their species, age, size, physical condition, and other physiological factors (e.g., health, feeding, and reproductive condition, accumulated tiredness) as well as on external factors, such as water temperature and velocity, moon cycles and seasons (Reiser \& Peacock, 1985; Larinier et al., 1994; Lucas \& Baras, 2001; Marmulla \& Welcomme, 2002). All of this makes extrapolation of fish pass requirements for different individuals within a particular species rather difficult, and it is even more difficult when compiling different fish species into one group. However, as the ICF is intended to be a strict but practical method, the average individual size for each species is considered together with information for Catalan fish fauna regarding jumping capacity, swimming power and creeping capacity, which are all considered important factors for overcoming obstacles (Larinier et al., 1994; Reiser \& Peacock, 1985; Jungwirth et al., 1998; Thorncraft \& Harris, 2000; Lucas \& Baras, 2001; Marmulla \& Welcomme, 2002; Amstrong et al., 2004).

Finally, classification of different native fish species in rivers from Catalonia was performed according to the most recent taxonomic classification available (Kottelat \& Freyhof, 2007; Leunda et al., 2009) and included four major groups corresponding to seaside species (G1), eels and similar species (G2), cyprinidae and similar species (G3) and trout and similar species (G4). Although this classification has been performed for fish species present in Catalan rivers (Table 1), it could be easily adapted to aquatic fauna for other geographical regions. 
Table 1. Grouping of the most characteristic fish species in Catalan continental waters that was used in the design of the ICF according to their ability to overcome obstacles and their presence in different types of river sections. Agrupación de las especies de peces más características de las aguas continentales catalanas, usadas para el diseño del ICF, en función de su capacidad para superar obstáculos y su presencia en diferentes tramos de la red fluvial.

\begin{tabular}{|c|c|c|}
\hline Group & Definition & Present species \\
\hline $\begin{array}{l}\text { Group 1 } \\
\text { (G1)-Littorals } \\
\text { and similar }\end{array}$ & $\begin{array}{l}\text { Migratory species (anadromous or amphidromous) with short or long distance } \\
\text { movements, with a moderate or low capacity to overcome obstacles }\end{array}$ & \\
\hline Group 1a (G1a) & Large species, with a moderate capacity to overcome obstacles & $\begin{array}{l}\text { Alosa alosa } \\
\text { Alosa fallax } \\
\text { Liza ramada } \\
\text { Chelon labrosus } \\
\text { Mugil cephalus }\end{array}$ \\
\hline Group 1b (G1b) & Small or benthic species, with a low capacity to overcome obstacles & $\begin{array}{l}\text { Atherina boyeri } \\
\text { Platichthys flesus } \\
\text { Petromyzon marinus }\end{array}$ \\
\hline $\begin{array}{l}\text { Group } 2 \\
\text { (G2)-eels and } \\
\text { similar }\end{array}$ & $\begin{array}{l}\text { Migratory species (catadromous), with long distance movements and high } \\
\text { capacity to overcome obstacles but not able to jump }\end{array}$ & Anguilla anguilla \\
\hline $\begin{array}{l}\text { Group } 3 \\
\text { (G3)-cyprinidae } \\
\text { and similar }\end{array}$ & $\begin{array}{l}\text { Intra-river migratory species (potamodromous) with a moderate or low } \\
\text { capacity to overcome obstacles }\end{array}$ & \\
\hline Group 3a (G3a) & Large species, with a moderate capacity to overcome obstacles & $\begin{array}{l}\text { Barbus meridionalis } \\
\text { Barbus haasi } \\
\text { Luciobarbus graellsii } \\
\text { Squalius laietanus } \\
\text { Parachondrostoma miegii } \\
\text { Cottus hispaniolensis }\end{array}$ \\
\hline Group 3b (G3b) & Small species, with little capacity to overcome obstacles & $\begin{array}{l}\text { Phoxinus bigerri } \\
\text { Phoxinus phoxinus } \\
\text { Barbatula quinardi } \\
\text { Salaria fluviatilis } \\
\text { Cobitis sp. } \\
\text { Achondrostoma arcasii } \\
\text { Gasterosteus aculeatus }\end{array}$ \\
\hline $\begin{array}{l}\text { Group } 4 \\
\text { (G4)-trout and } \\
\text { similar }\end{array}$ & $\begin{array}{l}\text { Intra-river migratory species (potamodromous) with a high capacity to } \\
\text { overcome obstacles, by swimming and/or jumping }\end{array}$ & Salmo trutta \\
\hline
\end{tabular}

\section{Classification of obstacles}

The ICF can be applied to any engineered infrastructure in rivers representing a longitudinal obstacle to fish movement. This index classifies infrastructures into three main groups according to their general morphology: (1) structures that water passes over by creating a small waterfall (e.g., dams or weirs; Fig. 1a), (2) structures in which water passes through one or several holes, with or without a small waterfall (e.g., culverts or holed crossings; Fig. 1b) and (3) structures with very little slope, where water passes over the struc- ture but does not generate a small waterfall (e.g., low slope weirs, bed sills or sediment stabilisation barriers; Fig. 1c).

\section{Fish pass classification}

According to international standards (Larinier $e t$ al., 1994; Thorncraft \& Harris, 2000; Marmulla \& Welcomme, 2002; Amstrong et al., 2004; Kroes et al., 2006), improving river longitudinal connectivity can be performed by means of two major kinds of solutions: (1) restoration solutions, which aim to improve the water quality or 


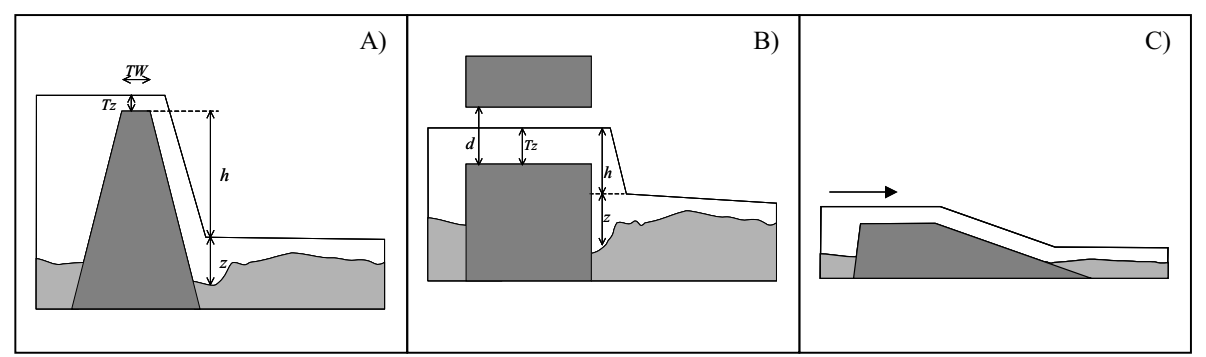

Figure 1. Illustrations and measurements of transverse obstacle types to which the ICF can be applied ( $d, h, T W, T z$ and $z$ as in block 1 in the appendix). A) Structures where water passes over the obstacle creating a small waterfall (weir type); B) structures where water passes through one or several holes, with or without a small waterfall (culvert type); C) structures with a very low slope, where water passes over and does not generate any small waterfall. Esquemas de las distintas tipologías de obstáculos transversales al río donde es de aplicación el ICF (d, h, TW, Tz y z como en el bloque 1 del apéndice). A) Estructuras donde el agua pasa por encima creando un salto (tipo azud); B) Estructuras donde el agua pasa por uno o varios orificios, con o sin salto (tipo vado agujereado); C) Estructuras con muy poca pendiente donde el agua resbala por encima y no genera salto.

river habitats through total or partial elimination of obstacles; (2) rehabilitation solutions, which focus on the installation of different types of fish passes and fish protection systems that prevent fish from entering derivation canals; or management solutions, such as implementation of environmental flow regimes or sustainable management of regulation floodgates. With respect to calculation of the ICF, the index disregards the evaluation of restoration or management solutions and focuses essentially on fish passes, categorising them into three main groups according to their morphology. The first group is comprised of close-to-nature facilities, such as fish ramps, bed ramps, lateral rivers or canals (Fig. 2a). These devices attempt to imitate the natural habitat in a specific river section. They are low-sloped canals or ramps with different sizes of blocks and stones allowing fish to move upstream and downstream. They can be placed at riverside locations (lateral rivers or canals) or in the main channel, either occupying its whole width (bed ramps) or only a part of it (ramps for fish). The second group consist of broadspectrum technical fish passes, where differentiation is made between longitudinal staircase section devices (Fig. 2b) and devices in which the longitudinal section has the appearance of a ramp (Fig. 2c). The index can be applied to any other assimilated structure in both cases. The longitudinal staircase section devices, such as pool fish passes (with or without a small waterfall, or with lateral slots), are based on division of a water- fall into small waterfalls, preferably under $10 \mathrm{~cm}$, inciting fish to jump from one pool to the next. These pools can be separated by cross-walls with central or lateral orifices allowing passage without jumping or by submerged holes in which benthic fish dwellers, creepers or modest swimmers can pass. The device in which the longitudinal section has the appearance of a ramp is comprised of baffle-type fish passes (such as deflectors or retarders), which allow the obstacle's height to be overcome along a slope that is relatively higher than the river but includes physical elements that decrease water speed. Finally, the third group of fish passes contains mechanised or specific technical pass devices, such as gates, lifts, locks and fish pumps, or devices specific to one or few species, such as eel ramps.

\section{Application of the ICF index}

\section{Previous knowledge-Desk work}

To apply the ICF, before a field visit is conducted, the potential native fish fauna must be known and classified according to the criteria shown in Table 1 , so that the fish groups that are potentially present can be determined. Subsequently, the timing of a sampling trip must be planned according to the river flow (see Basis of the ICF for details).

\section{Completion of field data sheets-Field work}

The field sheet for application of the ICF is divided into three blocks (see appendix). Blocks 1 

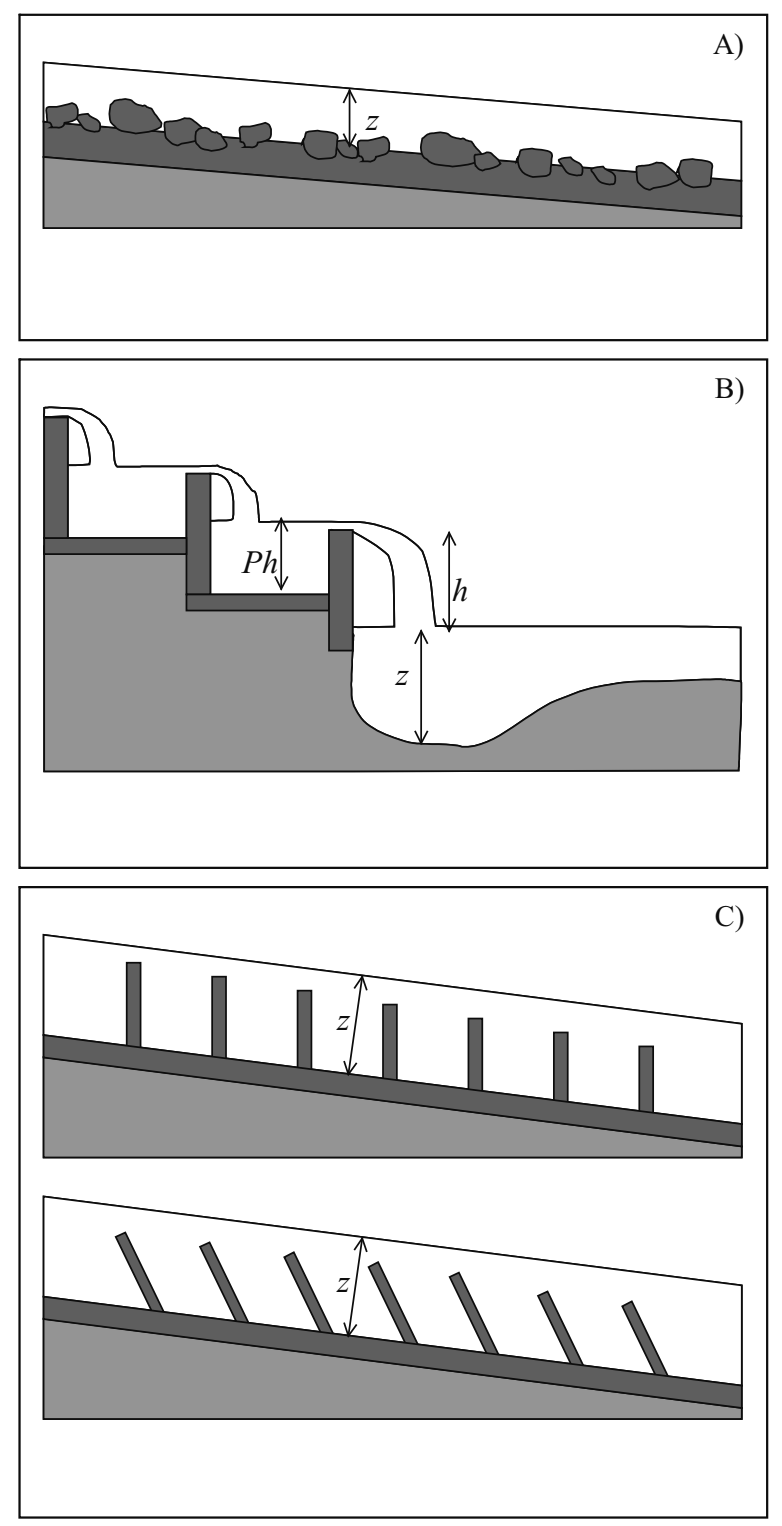

Figure 2. Illustrations and measurements of the different fish passes to which the ICF can be applied ( $h, P h$ and $z$ as in block 2 in the appendix). A) Fish passes close to natural conditions, such as fish ramps, lateral rivers or canals, or similar devices; B) broad-spectrum technical solutions such as pool sequences or similar structures; C) broad-spectrum technical solutions such as baffle type fish passes (deflectors, retarders) or similar structures. Esquemas de algunas de las distintas tipologías de dispositivos de paso de peces donde es de aplicación el ICF (h, Ph y z como en el bloque 2 del apéndice). A) Dispositivos de paso cercanos a la naturaleza: rampas para peces, canales o ríos laterales, o dispositivos asimilables; B) Dispositivos de paso técnicos de amplio espectro: estanques sucesivos o asimilables; C) Dispositivos de paso técnicos de amplio espectro: deflectores, ralentizadores, o asimilables. and 2 make reference to evaluation of the obstacle and fish pass, respectively. Different characteristics need to be measured for each type of obstacle or fish pass (if any). For each of them, a limiting value is given (maximum or minimum) for each of the groups of pre-established native fishes (Table 1). To the right of these values, there is an empty space that must be filled out in the field with the real value of the measurement for the obstacle or device. This value will preferably be measured, but if this is not possible, it can be estimated and specified on the field sheet. Block 3 includes different modulators from the results obtained in blocks 1 and 2. It also must be filled out in the field by marking all entries accomplished for the obstacle, the device/s and the riverside. Finally, it must be born in mind that any other relevant data, such as the sampling date, name of the obstacle and/or obstacle code, location, geographical coordinates, and incidence, must also be recorded; however, we do not include these data in these forms.

\section{Block 1-Obstacle evaluation}

Once the typology has been chosen for the obstacle out of the three possible types (Fig. 1), different characteristics will be measured or estimated, and the results will be written in the spaces on the right. For all types of obstacles, the morphology of river banks and riversides will also be evaluated. Surveyors will have to make a decision regarding whether they are suitable for determined creeping fish species to pass (i.e., eels) based on whether rough margins (e.g., presence of vegetation, roots, substrate heterogeneity), short slopes that are not too steep and particular humidity conditions exist (Larinier et al, 1994; Marmulla \& Welcomme, 2002; Amstrong et al., 2004). Moreover, surveyors must record whether water passes over or inside the obstacle; if there is no water movement, the obstacle must be considered impermeable (except to eels, if they can creep along riversides).

For dams, weirs or similar obstacles (Fig. 1a), surveyors need to take into account the following parameters. First, the height of the jump must be measured from the water surface at the bottom part 
of the jump to the highest point of the weir. If there is no water movement, the average weir height will be recorded. Second, the pool depth located immediately before the jump must be determined. This is extremely important for the fish to acquire impulse for their jump. A successful jump requires the water depth to be proportional to the height of the jump fishes must face. Third, the top width of the obstacle must be measured or estimated, although it is not directly valued in the index. Fourth, there must be a minimum depth of water on top of the obstacle to allow fish to swim, provided that the completion is wide enough (over $50 \mathrm{~cm}$ ); if not, a low flow will be sufficient.

For culverts or similar obstacles (Fig. 1b), surveyors need to measure the following characteristics. First, water velocity inside the fish pass must be measured. Due to a smaller section inside the culvert and to a lack of roughness, water velocity tends to increase a great deal and to be homogeneous all along a crossing, which makes the passage of fish very difficult or even impedes it altogether (Larinier, 2002a). Second, pass diameter, or height and width if its form is mainly square or rectangular, must be determined. Here there are three different cases: (1) there is a waterfall at the end of the pass; (2) water flows through the holes without any waterfall; and (3) water occupies the entire section of the hole (loading pipe). Third, the water depth inside the pass should allow fish species to swim. Fourth, if a small waterfall is generated, surveyors need to measure jumping height (Fig. 1a). Finally, surveyors will also need to assess pool depth before the jump.

For low slope weirs or similar obstacles (Fig. 1c), surveyors will assess only the ramp slope, water velocity at the ramp, and presence of turbulence at the base of the ramp, which might prevent fish from travelling up the obstacle. Once all measurements have been performed, surveyors are asked to compare field results and limiting characteristics for each fish group, so that they can determine which fish groups are able to overcome the obstacle. These groups will be marked at the end of block 1 and block 2 and at the beginning of block 3 .

\section{Block 2-Fish pass evaluation}

In the second block, all existing fish passes must be classified into the categories included in the ICF and then separately evaluated. If there is more than one fish pass, different sheets will be filled out for each of them, while if there is no pass, this should also be noted on the sheet. First, some general information on the fish pass conditions needs to be recorded regarding any obstruction impeding fish from passing at the entrance, the exit or within the pass. These obstructions can be temporary, being caused by the presence of tree trunks or a poor maintenance, or they can be caused by construction failures. If there is no water flowing, we must also consider this to represent an obstruction.

For fish passes that are close to natural conditions (Fig. 2a), four characteristics will be evaluated: first, the ramp slope; second, the water velocity in the fastest transect; third, the minimum average water depth in the section, evaluating whether there is sufficient depth for every fish group; and finally, the water depth in the pool located immediately before the jump if there are waterfalls.

In broad-spectrum fish passes (Fig. 2b) five characteristics need to be evaluated. The first is pool surface area, as a minimum pool size is needed to dissipate energy to avoid whirlpool formation and to sufficiently diminish turbulence. Pool size is also related to the amount of flow and, in some cases, to the existence of resting areas for fishes. Second, fish passes from one pool to the next need to be evaluated. Fish move from one pool to another through lateral slots, notches or submerged orifices in the cross-walls that separate the different pools as well as by overcoming small waterfalls. In this regard, slot width and the maximum and average waterfall height formed between on pool and the next (unevenness) need to be measured. Third, pool depth also needs to be measured, as a certain depth is required to overcome a jump if there is one, or to allow swimming, resting and energy dissipation. Fourth, water velocity between pools must be de- 
termined because this is one of the main limiters for swimming fish. Finally, surveyors need to qualitatively assess whether there is strong turbulence inside pools.

In broad-spectrum technical passes, such as baffle fish passes (Fig. 2c), the limiting characteristics that surveyors need to evaluate are slope, water depth and water velocity, while the evaluation of gates, lifts, locks and pumps could imply a much more complex analysis (preferably performed by means of in situ monitoring), and thus, the ICF only evaluates their presence positively. Finally, to evaluate eel ramps, limiting characteristics such as slope, water velocity and width should be considered by the surveyors.

\section{Block 3-Modulators and final score}

The ICF score from blocks 1 and 2 can be 75, 50, 25 or 0 depending on whether an obstacle with or without a fish pass is permeable to all potential fish groups, only to some groups, only to one fish group or if it is not permeable to any group, respectively, considering all subgroups (G1a, G1b, G2, G3a, G3b, G4) separately. When there is only one potential fish group, as in high mountain streams (for example, G4, in a trout river), the maximum score (75) will be assigned if fish can pass and the minimum (0) if they cannot pass. If there are only two potential groups in a section and only one of them can pass, a score of 50 points will be given. This score is then modulated based on inspection of complementary attributes (block 3) that make reference to additional characteristics of the obstacle, the fish pass, or fish migration downstream, and which may occur in a different hydrological situation than that of the sampling day.

The modulators considered for the obstacle are positive when water passes over one or both sides of the obstacle generating a lateral river flow, especially in high flow situations, which can be suitable for fish to pass, and when the obstacle is not very steep (slope $<45 \%$ ) and its surface is rough and irregular. The modulators are negative when any overhanging structure is present at any point within the infrastructure. Regarding fish passes, the ICF includes 2 positive and 4 negative modulators. The first positive modulator is the presence of a natural substrate inside the fish pass with similar characteristics to the substrate in the river (this increases the possibility of reducing the speed of water in some areas and creates small sitting areas). The second positive modulator is the existence of an appropriate entrance location, which must be easily found by fishes and is preferably located as close as possible to the obstacle (Larinier, 2002b). This includes the existence of an appealing flow (a "call" flow) either in the fish pass or close to it and the absence of dead areas between the entrance and the obstacle. In lateral rivers or canals, the impossibility of placing the entrance close to the obstacle must be solved by increasing the amount of flow through the fish pass (Larinier, 2002c). The first negative modulator is an inappropriate location of the fish pass that hinders or prevents fish entry, and the second is fish pass width, which is considered inefficient if it is narrower than $1 / 20$ of the river's width. The third negative modulator is based on the need for management activity or constant maintenance of the fish pass to guarantee its efficiency, e.g., associated with passes with gates or partition walls, or those with a tendency to accumulate debris affecting the water or fish pass. Finally, fish passes that are in bad condition or damaged are also considered negatively.

The last set of modulators deals with fish migration downstream and include 2 positive and 2 negative modulators. The first positive modulator addresses the existence of a low-rise fall and a sufficient water depth in the pool below the obstacle to warrant a safe migration downstream for all fish groups or a close-to-nature fish pass (ramps and lateral rivers or canals). The second is the existence of mechanisms (mechanical, light, sound or electrical) to prevent or minimise the entrance of fish into derivation canals. The first negative modulator is the absence of mechanisms to prevent entrance into derivation canals, and the second is the possibility of migration occurring over the obstacle with any risk of mortality for fish. All entries accomplished will be marked in the three groups of modulators, and the values will be added or deducted from the score obtained in block 1 and 2 , with the minimum final score being 0 . 
Table 2. Quality classes and score ranges of the ICF index and general interpretation. Clases de calidad y rangos de puntuaciones de calidad del índice ICF e interpretación general.

\begin{tabular}{lcl}
\hline Range & Quality & \\
\hline$\geq 95$ & Very Good & $\begin{array}{l}\text { All the potentially present groups of fish can pass in nearly any hydrological situation. Absence of obstacles } \\
\text { for fishes or existence of a partial or total demolition of an obstacle. }\end{array}$ \\
\hline $75-94$ & Good & $\begin{array}{l}\text { The majority of the potentially present fish groups can pass in nearly any hydrological situation. Presence of } \\
\text { a small obstacle or with a good fish pass. }\end{array}$ \\
\hline $50-74$ & Moderate & $\begin{array}{l}\text { The majority or some of the potentially present fish groups can pass, in any or in some hydrological } \\
\text { situations. Presence of a relatively permeable obstacle for fishes with too specific or little functional fish } \\
\text { pass. }\end{array}$ \\
\hline $25-49$ & Poor & $\begin{array}{l}\text { Only one or few species of the potentially present fish groups can pass, and in determined hydrological } \\
\text { situations. Presence of an obstacle with very specific or very little functional fish pass. }\end{array}$ \\
\hline$<25$ & Bad & $\begin{array}{l}\text { No species of the potentially present fish groups or only some in very exceptional hydrological situations } \\
\text { can pass. Presence of a quite big obstacle without any fish pass/es or with little or non functional fish pass. }\end{array}$ \\
\hline
\end{tabular}

\section{ICF index results}

ICF index values range from 0 to 110 , which can classify obstacles into five quality levels, as shown in Table 2. The ICF considers an obstacle as permeable if there is/are one or more effective fish passes (very good ICF) allowing $95 \%$ of all species and individuals to pass through (both upstream and downstream) that correctly operate under approximately $95 \%$ of the flow conditions known for each site (Mallen-Cooper, 1993 in Thorncraft \& Harris, 2000). In contrast, the ICF considers an obstacle or a fish pass not to be permeable (bad ICF) when it does not allow any species or only allows some individuals to pass through under exceptional hydrological situations. A wide range of intermediate situations canbe described, which are integrated in the other three ICF categories (good, moderate and poor).

\section{Changes introduced in this new version of the ICF index}

The first ICF version published was developed under a general evaluation protocol for the hydromorphological quality in rivers developed by the Agència Catalana de l'Aigua (HIDRI-protocol; ACA, 2006). The structure in the new version of the ICF has been changed with the aim of making it simpler and facilitating the calculation of the different blocks. Thus, fish are grouped in four groups instead of the five groups in the original version, and large littoral species with better swimming skills are separated from small species into groups 1a and 1b, respectively. Moreover, we substituted the need to obtain partial results in the two first blocks regarding the obstacle typology and fish pass by obtaining a joint, provisional punctuation in the third block. A slight modification of the limiting values for fish groups, both for obstacles and for fish passes, has also been included. Finally, the punctuation obtained within the first two blocks is weighted with a series of modulators to obtain the final score, and the quality of the categories obtained is interpreted in this new version.

\section{ICF application in Catalonia}

The ICF was tested in 101 infrastructures in different Catalan rivers, mainly in the Ebro (37\%) and Garona ( $29 \%)$, followed by the Ter $(15 \%)$ and Llobregat (12\%), with only between 1 and 3 infrastructures visited in the Muga, Daró, Tordera and Besòs rivers (Fig. 3). More than $80 \%$ of these infrastructures were weirs $(0.5$ and $10 \mathrm{~m}$ height), with the rest being bridge and railway bases, gauging stations and large dams (>10 m). Moreover, 80 of these infrastructures were associated with some kind of restoration solution or fish pass. Over half of these solutions (54\%) belonged to broad-spectrum technical solutions, such as sequences of pools (Fig. 2b) both with and without waterfalls between pools or with lateral slots, while $13 \%$ belonged to technical solutions, such as baffle fishways (Fig. 2c), and $8 \%$ 


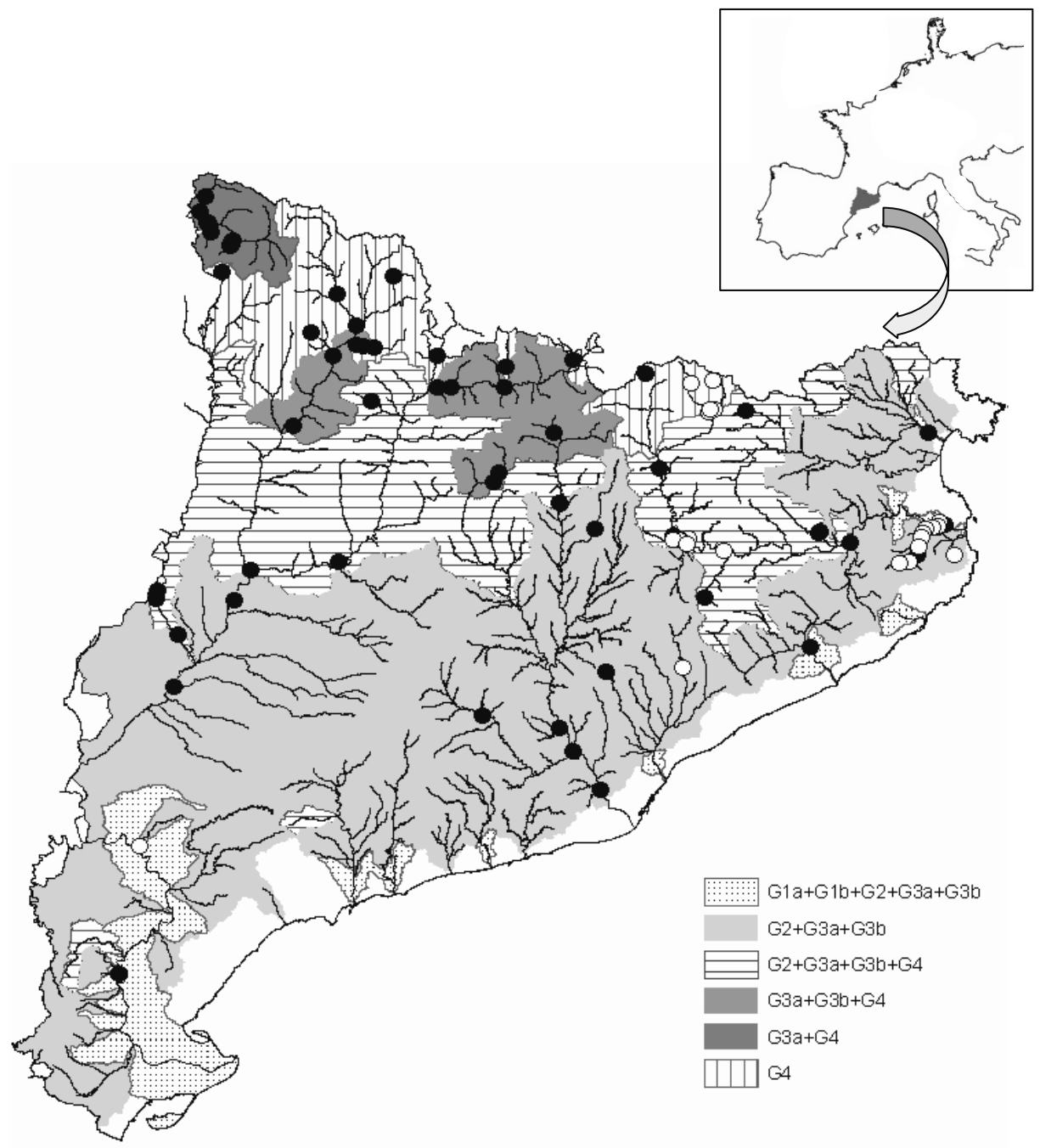

Figure 3. Potential distribution of native continental species in the Catalan area grouped according to their capacity to overcome obstacles (Table 1: modified from ACA, 2006) and locations of the obstacles evaluated in the present study (•: obstacles with fish pass; ○: obstacles without fish pass). Distribución potencial de las especies de peces continentales autóctonas de Catalunya, agrupadas según su capacidad para superar obstáculos (Tabla 1: modificado a partir de ACA, 2006) y localización de los obstáculos evaluados en el presente estudio ( $\bullet$ : obstáculos con dispositivos de paso para peces; o: obstáculos sin dispositivos de paso para peces).

were close to natural solutions (ramps; Fig. 2a). Two lifts for fishes and 4 slides or flat ramps were also identified. Furthermore, 14 obstacles were partially demolished, which represents a solution different from a fish pass; these cases were assimilated into a broad-spectrum technical solution with a longitudinal stair-shaped section regarding ICF calculations. For each infrastructure, both the old (ACA, 2006) and new versions of the ICF were calculated.

\section{RESULTS}

Application of the new ICF version to 101 obstacles with and without fish passes in rivers from Catalonia resulted in obstacles being represented in all five quality classes of river connectivity (Fig. 4), while the old version of the ICF yielded no obstacles in the very good quality class. The main difference between the two versions was that when using the old ICF, over half of the obstacles were classified 
A)

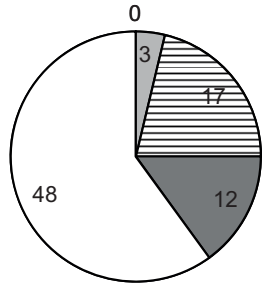

C)

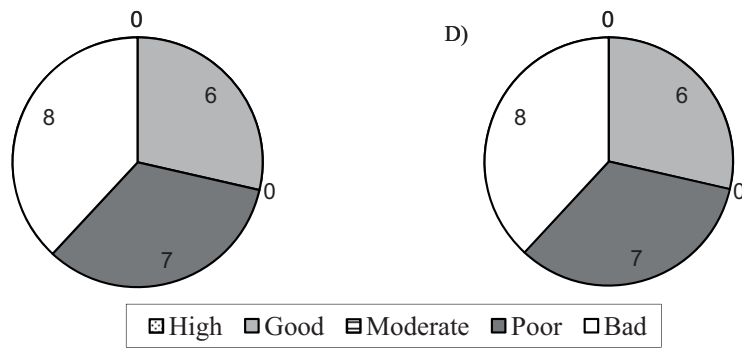

Figure 4. Quality classification of the 101 obstacles evaluated with (A) the old version of the ICF (ACA, 2006) for obstacles with fish passes, (B) the new version of the ICF for obstacles with fish passes, (C) the old version of the ICF for obstacles without fish passes and (D) the new version of the ICF for obstacles without fish passes. Clasificación en rangos de calidad de los 101 obstáculos evaluados con (A) versión antigua del ICF (ACA, 2006) aplicada en los obstáculos con dispositivos de paso para peces, (B) versión actual, presentada aquí, aplicada en los obstáculos con dispositivos de paso para peces, (C) versión antigua del ICF (ACA, 2006) aplicada en obstáculos sin dispositivos de paso para peces, y (D) versión actual aplicada en obstáculos sin dispositivos de paso para peces.

into the bad quality class, despite the existence of fish passes, and only 9 of them achieved a good connectivity classification, while the new version discriminated better among the quality classes, and more than $20 \%$ of the obstacles at least achieved a good quality classification (Fig. 4). Additionally, 17 obstacles even achieved a very good connectivity classification because they were partial or small obstacles associated with fish passes close to natural conditions.

The differences in the connectivity assessment between the two ICF versions mainly appeared for those obstacles with fish passes because obstacles without fish passes were classified into the same quality class by both versions (Fig. 4). The new ICF version considerably increased the classification quality of obstacles with fish passes (Fig. 4). Table 3 shows the results for 17 of the 101 obstacles evaluated, which represent the diversity of obstacles and fish passes evaluated.

\section{DISCUSSION}

The results of the present study show that the new ICF version generally increases the final score of those obstacles with fish passes in comparison with the score obtained using the old version. Moreover, the results obtained with the new ICF version could be considered coherent with the degree of real permeability of the obstacles (with or without fish passes). In this regard, seven obstacles with different fish pass typologies were monitored with in situ measurements of fish fauna movements (Ordeix et al., 2009b \& 2011), yielding results completely coincident with the evaluation of the new ICF version (see Ordeix et al., 2011). In contrast, the evaluations of connectivity for fish in Catalan rivers conducted by several consultants and research centres (Ferrer et al., 2009; Ordeix et al., 2006; Rocaspana et al., 2009) through calculation of the old ICF version (ACA, 2006) might have yielded negative skewed results for obstacles with fish passes.

\section{The ICF and the WFD}

River longitudinal connectivity is one of the hydromorphological quality attributes required by the WFD to evaluate hydromorphological quality, but despite the many methods that have been developed for assessing the integrity of hydrological and morphological conditions, there are hardly any such methods for river longitudinal connectivity. The more widely used methods for assessing hydromorphological conditions in European rivers, such as the River Habitat Survey in the United Kingdom (Raven et al., 1998), its adaptation to Italy (Buffagni et al., 2005), the System for Evaluating Rivers for Conservation in Scotland (Boon et al., 1997 \& 1998), the Système d'Evaluation de la Qualité Physique in France (Agences de l'Eau, 2002), the Large River Survey in Germany (Fleischhacker \& Hern, 2002), the Danish Stream Habitat Index in Denmark (Pedersen \& Baattrup-Pedersen, 2003), and even the recently approved CEN rule (European Committee for Standardization-CEN, 2010), record the presence of transverse obstacles, but they do not quantify the degree to which the obstacles 
Table 3. Results from application of the old and the new versions of the ICF to 17 obstacles with and without fish passes in Catalan rivers (original data obtained from Ordeix et al., 2006). Ejemplos de resultados del ICF, antiguo y nuevo, obtenidos con varias tipologías de obstáculos de los ríos de Catalunya, sin o con dispositivos de paso para peces (datos originales de Ordeix et al., 2006).

\begin{tabular}{|c|c|c|c|c|c|c|}
\hline Stream name & Location & Obstacle & Fish pass & Fish pass description & $\begin{array}{c}\text { ICF } \\
\text { Old version }\end{array}$ & $\begin{array}{c}\text { ICF } \\
\text { New version }\end{array}$ \\
\hline Ter & Vilanova de Sau & $\begin{array}{l}\text { Hydropower station, dam } \\
>10 \mathrm{~m}\end{array}$ & Non-existent & & Bad & Bad \\
\hline Ter & Manlleu & $\begin{array}{l}\text { Hydropower station, weir } \\
<10 \mathrm{~m}\end{array}$ & Non-existent & & Bad & $\mathrm{Bad}$ \\
\hline Ter & Camprodon & Collector crossing the river & Non-existent & & Poor & Poor \\
\hline Ter & Ullà & Agricultural, weir $<10 \mathrm{~m}$ & Non-existent & & Poor & Poor \\
\hline Daró & Gualta & Culvert & Non-existent & & Good & Good \\
\hline Gurri & Gurb & Culvert & Non-existent & & Poor & Poor \\
\hline Meder & Vic & Bed sill & Non-existent & & Poor & Poor \\
\hline Congost & La Garriga & Bed sill & Non-existent & & Good & Good \\
\hline Garona & Vielha & Bed sill & Restoration & Partial demolition & Moderate & Very good \\
\hline Muga & $\begin{array}{l}\text { Castelló } \\
\text { d'Empúries }\end{array}$ & Gauging station & Close to nature & Fish ramp & Poor & Good \\
\hline Daró & $\begin{array}{l}\text { La Bisbal } \\
\text { d'Empordà }\end{array}$ & Bridge base & Close to nature & Bed ramp & Good & Very good \\
\hline Noguera Pallaresa & Sort & $\begin{array}{l}\text { Hydropower station, weir } \\
<10 \mathrm{~m}\end{array}$ & Broad-spectrum & $\begin{array}{l}\text { Following pools with small } \\
\text { waterfalls }\end{array}$ & $\mathrm{Bad}$ & Moderate \\
\hline Llobregat & Castellbisbal & Gauging station & Broad-spectrum & $\begin{array}{l}\text { Following pools with small } \\
\text { waterfalls }\end{array}$ & $\mathrm{Bad}$ & Bad \\
\hline Garona & Les & Bed sill & Broad-spectrum & Baffle type (deflectors) & Bad & Good \\
\hline Riu de la Llosa & Lles de Cerdanya & Bridge base & Broad-spectrum & Baffle type (deflectors) & $\mathrm{Bad}$ & $\mathrm{Bad}$ \\
\hline Aigua de Valls & Guixers & Agricultural, weir $<10 \mathrm{~m}$ & Broad-spectrum & Baffle type (retarders) & Bad & Poor \\
\hline Santa Magdalena & Llavorsí & $\begin{array}{l}\text { Hydropower station, dam } \\
>10 \mathrm{~m}\end{array}$ & $\begin{array}{l}\text { Mechanized or sp. } \\
\text { solution }\end{array}$ & Lifts for fishes & Moderate & Good \\
\hline
\end{tabular}

affect river connectivity for fishes. This study shows that the new ICF version improves longitudinal connectivity assessment for fishes compared to the older version, and thus it constitutes an appropriate method for evaluation of longitudinal connectivity. Furthermore, the ICF discriminates five permeability classes, which assists in the integration of this method with other hydromorphological quality elements within the context of the WFD. For example, this is the case in the HIDRI evaluation protocol (ACA, 2006), in which the ICF is integrated with other methods to evaluate other hydrological and morphological river attributes. Finally, the scores from all of the different blocks can yield valuable and precise information on the type and magnitude of the problems caused by each obstacle, and as a con- sequence, could be used to appropriately orient measures and priorities.

As defined in the WFD, a very good status regarding longitudinal connectivity can only be achieved when the migration of aquatic organisms and sediment transport are not altered (EC, 2000). In most cases, the existence of an obstacle transverse to the river affects species migration and/or sediment transport in some way. Even with fish pass solutions considered to be effective, the complete integrity of populations is not ensured because long-term effects are unknown. In this regard, it has been pointed out that delays in overcoming an obstacle can lead to reduced migration rates, increase fish fatigue and limit certain fish sizes (Porcher \& Travade, 2002). It is for this reason that achieving a very 
good status of the ICF index is quite difficult because it is only possible for small obstacles with close to natural fish passes, or partial obstacles (constructed to retain water only at the margins of rivers or that are partially demolished) where floods allow fauna and sediments to pass in a similar way to small natural waterfalls.

\section{The ICF and management processes}

The use of the ICF can be extended not only to evaluation of hydromorphological quality but also as part of management strategies to improve river longitudinal connectivity. In this regard, the ICF could be used in different stages of the management process for improvement of river longitudinal connectivity.

In the preliminary stage of the management process, the parameters recorded on the field sheet allow a generic and preliminary identification of the possible reasons for the lack of longitudinal connectivity to be performed, which can contribute to the design of more efficient correction measures. In the medium term, the ICF can be used together with fish indices to monitor the effects of longitudinal obstacles (upstream and downstream). Given the slow response of fishbased indicators to improvements in connectivity, most fish indices are not useful in the short term (but see Zitek et al., 2008). Moreover, determining which fish species and individuals travel through fish passes is the best way to evaluate the degree to which they can overcome an obstacle. However, the cost of such an evaluation might be prohibitive when covering large areas. On the other hand, the ICF can be used from the very first moment of the diagnosis phase because it is based on biological traits of the potential fish fauna and allows performing a costeffective evaluation of river longitudinal connectivity for large areas. Finally, a regional database of ICF scores assists in identifying priority areas for restoration, as key or endangered species might be affected, or longer river sections could be improved. There are currently different methods for prioritising measures to re-establish river connectivity (Pini Prato, 2007; Mader \& Maier, 2008), which can be adapted and complemented by the ICF index in Catalan rivers (ACA, 2009). Finally, once all restoration measures for longitudinal connectivity have been implemented, the ICF could be used to evaluate the efficiency of the management measures employed.

Although a total restoration of river longitudinal connectivity is only possible by demolishing obstacles (Zitek et al., 2008), the use of river ecosystems by humans prevents this situation, and thus, rehabilitation measures should ensure the re-establishment of at least a good ecological status (sensu WFD) of rivers. This rehabilitation should include effective fish passages, but also habitat recovery and connection with well-preserved source areas (Zitek et al., 2008). Similarly, implementation of environmental flow regimes is urgently needed because without this, other measures could be useless. In this respect, the ICF can be a reliable and useful tool to diagnose and to improve the hydromorphological quality of rivers in relation to longitudinal continuity, and it is highly valuable when integrated with other methods for evaluation of hydromorphological quality, such as in the HIDRI protocol used in Catalan rivers (ACA, 2006).

\section{ACKNOWLEDGEMENTS}

The authors wish to especially thank all of the contributions received from all those people, consultants and research teams who have applied the first version of the ICF (ACA, 2006) and who have sent us their results and comments. We also want to thank two anonymous reviewers for helping us to improve the manuscript with their comments and corrections.

\section{REFERENCES}

AGENCES DE L'EAU. 2002. Système d'Evaluation de la Qualité Physique (hydromorphologique) des cours d'eau français. SEQ Physique (version $v 0^{\prime}$ ). Document de travail en cours de validation. Ministère de l'Ecologie et du Développement Durable, France. 38 pp.

AGÈNCIA CATALANA DE L'AIGUA (ACA). 2005. Caracterització de masses d'aigua $\mathrm{i}$ anàlisi del 
risc d'incompliment dels objectius de la Directiva marc de l'aigua (2000/60/CE) a Catalunya (conques intra $\mathrm{i}$ intercomunitàries), en compliment als articles 5, 6 i 7 de la Directiva. Departament de Medi Ambient i Habitatge, Generalitat de Catalunya. 860 pp. Available in internet: http://aca-web. gencat.cat/aca/appmanager/aca/aca?_nfpb=true\&_ pageLabel=P1206154461208200586461.

AGÈNCIA CATALANA DE L'AIGUA (ACA). 2006. HIDRI. Protocolo para la valoración de la calidad hidromorfológica de los ríos. Departament de Medi Ambient i Habitatge, Generalitat de Catalunya. 158 pp. Available in internet: http://aca-web. gencat.cat/aca/appmanager/aca/aca?_nfpb=true\&_ pageLabel=P1206254461208200588613\#fragment-1.

AGÈNCIA CATALANA DE L'AIGUA (ACA). 2009. Trabajos para la redacción de las "Bases técnicas para el desarrollo del Programa de Medidas enfocado a la mejora de la conectividad fluvial en Catalunya". Departament de Medi Ambient i Habitatge, Generalitat de Catalunya. Available in internet: http://www.gencat.cat/aca.

AMSTRONG, G. S., M. W. APHRAHAMIAN, G. A. FEWINGS, P. J. GOUGH, N. A. READER \& P. V. VARALLO. 2004. Environment Agency Fish Pass Manual: Guidance Notes on the Legislation, Selection and Approval of Fish Passes in England and Wales. Environment Agency. Wales. United Kingdom. 313 pp.

APARICIO, E., M. J. VARGAS, J. M. OLMO \& A. SOSTOA. 2000. Decline of native freshwater fishes in a Mediterranean watershed on the Iberian Peninsula. Environmental Biology of Fishes, 59(1): 11-19.

BOON P. J., N. T. H. HOLMES, P. S. MAITLAND, T. A. ROWALL \& J. DAVIES. 1997. A system for evaluating rivers for conservation (SERCON): development structure and function. In: Freshwater Quality: Defining the Indefinable? P. J. Boon \& D. L. Howell (eds.): 299-326. The Stationery Office, Edimburgh. Scotland. United Kingdom.

BOON, P. J., J. WILKINSON \& J. MARTIN. 1998. The application of SERCON (System for Evaluating Rivers for Conservation) to a selection of rivers in Britain. Aquatic Conservation, Marine and Freshwater Ecosystems, 8: 597-616.

BUFFAGNI, A., M. CIAMPITIELLO \& S. ERBA. 2005. Il rilevamento idromorfologico e degli habitat fluviali nel contesto della Direttiva Europea sulle Acque (WFD): principi e schede di appli- cazione del metodo CARAVAGGIO. Notiziario dei Metodi Analitici, 2: 32-46.

BRUSLÉ, J. \& J. P. QUIGNARD. 2001. Biologie des poissons d'eau douce européens. Editions Tec\&Doc. Paris. France. 625 pp.

CASALS, F. 2005. Les comunitats íctiques dels rius mediterranis: relacions amb les condicions ambientals. Ph.D. Thesis. University of Barcelona. $353 \mathrm{pp}$.

CATALAN, J., R. VILALTA, B. WEITZMANN, C. PIGEM, M. VENTURA, R. ARANDA \& E. COMAS. 1997. L'obra hidràulica en els Pirineus. Avaluació, correcció $i$ prevenció de l'impacte mediambiental. ENHER, FECSA i Fundació La Caixa. Barcelona. Catalonia. 583 pp.

CEN. 2010. EN 15843:2010 Water quality-Guidance standard on determining the degree of modification of river hydromorphology.

COWX, I. G. \& R. L.WELCOMME (eds.). 1998. Rehabilitation of rivers for fish. Food and Agriculture Organization of the United Nations (FAO) by Fishing News Books (Blackwell Science Ltd). Oxford and Northampton, United Kingdom. 260 pp.

EC. 1992. Council Directive 92/43/EEC of 21 May 1992 on the conservation of natural habitats and of wild fauna and flora.

EC. 2000. Directive 2000/60/EC of the European Parliament and of the Council of 23 October 2000 establishing a framework for Community action in the field of water policy. Official Journal of the European Communities.

EC. 2007. Council Regulation (EC) No 1100/2007 of 18 September 2007 establishing measures for the recovery of the stock of European eel.

ELVIRA, B., G. G. NICOLA \& A. ALMODÓVAR. 1998a. Impacto de las obras hidráulicas en la ictiofauna. Dispositivos de paso para peces en las presas de España. Colección técnica. Organismo Autónomo de Parques Naturales. Ministerio de Medio Ambiente. Madrid. Spain. 208 pp.

ELVIRA, B., G. G. NICOLA, \& A. ALMODÓVAR. 1998b. Sistemas de paso para peces en presas. Centro de Estudios y Experimentación de Obras Públicas. Madrid. Spain. 116 pp.

ENCINA, L., A. RODRÍGUEZ, C. GRANADO \& C. ESCOT. 2001. Gestión y evaluación de embalses: estudio de las poblaciones de peces. Servicio de Publicaciones de la Universidad de Sevilla. Sevilla. Spain. 224 pp.

FERRER, D., R. GARCÍA \& L. XIFRA. 2009. Estudi de la connectivitat longitudinal del riu Fluvià i la seva aplicació per a la gestió de l'anguila euro- 
pea (Anguilla anguilla) (Technical report). University of Girona. 290 pp. Available in internet: http: //dugi-doc.udg.edu/bitstream/10256/1733/1/1\%20 MEM\%C3\%92RIA.pdf.

FLEISHHACKER, T. \& K. HERN. 2002. Ecomorphological survey of Large Rivers. German Federal Institute of Hydrology. Koblenz. Germany. 41 pp.

GEERAERTS, C., M. OVIDIIO, H. VERBIEST, D. BUYSSE, J. COECK, C. BELPAIRE \& J. C. PHILIPPART. 2007. Mobility of individual roach Rutilus rutilus (L.) in three weir-fragmented Belgian rivers. Hydrobiologia, 582: 143-153.

JUNGWIRTH, M., S. SCHMUTZ \& S. WEISS (eds). 1998. Fish migration and Fish Bypasses. Fishing News Books, Blackwell Science Ltd. Cambridge. United Kingdom. 438 pp.

KOTTELAT, M. \& J. FREYHOF. 2007. Handbook of European Freshwater Fishes. Publications Kottelat. Cornol. Switzerland. 646 pp.

KROES, M. J., P. GOUGH, H. WANNINGEN, P. P. SCHOLLEMA, M. ORDEIX \& D. VESELÝ. 2006. From sea to source. Practical guidance for the restoration of fish migration in European Rivers. Interreg IIIC Project "Community Rivers". Hunze en Aa's Water Board. Gröningen, The Netherlands. 119 pp.

LARINIER, M. 2001. Environmental issues, dams and fish migration. In: Dams, fish and fisheries. Opportunities, challenges and conflict resolution. G. Marmulla (ed.): 45-89. Food and Agriculture Organization of the United Nations (FAO), Rome, Italy.

LARINIER, M. 2002a. Fish passages through culverts, rock weirs and estuarine obstructions. Bull. Fr. Pêche Piscic. 346 suppl.: 119-134.

LARINIER, M. 2002b. Location of fishways. Bull. Fr. Pêche Piscic. 346 suppl.: 39-53.

LARINIER, M. 2002c. Pool fishways, pre-barrages and natural bypass channels. Bull. Fr. Pêche Piscic. 346 suppl.: 54-82.

LARINIER, M., J. P. PORCHER, F. TRAVADE \& C. GOSSET. 1994. Passes à poissons. Expertise et conception des ouvrages de franchissement. Collection Mise au point. Conseil Supérieur de la Pêche. París. 336 pp.

LEUNDA, P. M., B. ELVIRA, F. RIBEIRO, R. MIRANDA, J. OSCOZ, M. J. ALVES \& M. J. COLLARES PEREIRA. 2009. International Standardization of Common Names for Iberian Endemic Freshwater Fishes. Limnetica, 28 (2): 189-202.
LUCAS, M. C. \& E. BARAS. 2001. Migration of Freshwater Fishes. Blackwell Science. Oxford, United Kingdom. 420 pp.

MADER, H. \& C. MAIER. 2008. A method for prioritizing the reestablishment of river continuity in Austrian rivers. Hydrobiologia, 609: 277-288.

MALLEN-COOPER, M. 1993. Proceedings of the workshop on fish passage in Australia. Fisheries Research Institute. Cornulla. Australia. 21 pp.

MARMULLA, G. \& R. L. WELCOMME (eds.). 2002. Fish passes. Design, dimensions and monitoring. Food and Agriculture Organization of the United Nations (FAO) \& Deutscher Verband für Wasserwirtschaft und Kulturvau (DVWK). Roma. Italy. 118 pp.

MARTÍNEZ, C. \& J. A. FERNÁNDEZ. 2006. Índices de Alteración Hidrológica en ecosistemas fluviales. Monografías CEDEX. Ministerio de Fomento-Ministerio de Medio Ambiente. Madrid. Spain. 178 pp.

MARTÍNEZ, C. \& J. A. FERNÁNDEZ. 2007. Índices de Alteración Hidrológica (IAH): una nueva metodología para la caracterización de la integridad hidro-ecológica de los ríos. Proceedings of the II Congreso sobre Restauración de ríos y humedales. Tarragona. Catalonia.

ORDEIX, M., Q. POU-ROVIRA, N. SELLARÈS, A. MUNNÉ, J. PAGÈS \& C. SOLÀ. 2006. Avaluació dels dispositius de pas per a peixos per a l'anàlisi de la connectivitat als rius de Catalunya. Agència Catalana de l'Aigua, Departament de Medi Ambient i Habitatge, Generalitat de Catalunya. 289 pp. Available in internet: http://www.gencat.cat/aca.

ORDEIX, M., J. VAN HERK, H. WANNINGEN, C. PINTOR \& C. DURÁN. 2009a. Asistencia técnica para el estudio de propuestas de mejora de la conectividad para los peces en la parte baja del río Ebro. CERM, Centre d'Estudis dels Rius MediterranisMuseu Industrial del Ter, LINKit Consult \& Wanningen Water Consult. Done for the Confederación Hidrográfica del Ebro. Zaragoza. Spain. 48 pp. Available in internet: http://www.gencat.cat/aca.

ORDEIX, M., Q. POU-ROVIRA, N. SELLARÈS, A. MUNNÉ, M. BARDINA, C. SOLÀ \& J. PAGÈS. 2009b. Avaluació de l'eficàcia de sis dispositius de pas per a peixos dels rius de Catalunya. Anys 2006-2009. Treballs preliminars a la redacció del Pla de Millora de la Connectivitat fluvial a Catalunya. Agència Catalana de l'Aigua, Depar- 
tament de Medi Ambient i Habitatge, Generalitat de Catalunya. 189 pp. Available in internet: http: //www.gencat.cat/aca.

ORDEIX, M., Q. POU-ROVIRA, N. SELLARÈS, M. BARDINA, A. CASAMITJANA, C. SOLÀ \& A. MUNNÉ. 2011. Fish passes assessment in the rivers of Catalonia (NE Iberian Peninsula). A case study of weirs associated to hydropower plants and gauging stations. Limnetica, 30(2), 405-426.

PEDERSEN, M. L. \& A. BAATTRUP-PEDERSEN. 2003. National monitoring programme 2003-2009. Assessment methods manual. Technical Report no. 21. National Environmental Research Institute of Denmark. 73 pp.

PINI PRATO, E. 2007. Descrittori per interventi di ripristino della continuità fluviale: Indici di Priorità di Intervento. Biologia Ambientale, 21 (1): 9-16.

PORCHER, J. P. \& F. TRAVADE. 2002. Fishways: biological basis, limits and legal considerations. Bull. Fr. Pêche Piscic., 346 suppl.: 9-20.

RAVEN, P. J., N. T. H. HOLMES, F. H. DAWSON, P. J. A. FOX, M. EVERARD, I. R. FOZZARD \& K. J. ROUEN. 1998. River Habitat Qualitythe physical character of rivers and streams in the $U K$ and Isle of Man. Environment Agency. Bristol. United Kingdom. 85 pp.

REISER, D. W. \& R. T. PEACOCK. 1985. A technique for assessing upstream fish passage problems at small-scale hydropower developments. Symposium on small hydropower and fisheries. American Fisheries Society, Western Division, Bethesda, Maryland: 423-432.

RICHTER, B. D., J. V. BAUMGARTNER, J. POWEL \& D. P. BRAUN. 1996. A method for assessing hydrologic alteration within ecosystems. Conservation Biology, 10: 1163-1174.

ROCASPANA, R., R. GUILLEM \& C. POU. 2009.
Estudi sobre la connectivitat ecològica en la xarxa hidrogràfica del Parc Natural de l'Alt Pirineu. Parc Natural de l'Alt Pirineu. Departament de Medi Ambient i Habitatge. Generalitat de Catalunya. 66 pp. Available in internet: http://www20.gencat. cat/portal/site/parcsnaturals/menuitem.5fed2e $7 f 93$ c785920161 fea3b0c0e1a0/?vgnextoid=03c5bbf55 7a9b210VgnVCM1000008d0c1e0aRCRD\&vgnext channel=03c5bbf557a9b210VgnVCM1000008d0 c1e0aRCRD\&vgnextfmt=default.

RODRÍGUEZ-RUIZ, A. \& C. GRANADO-LORENCIO. 2006. Spawning period and migration of three species of cyprinids in a stream with Mediterranean regimen (SW Spain). Journal of Fish Biology, 41(4): 545-556.

RONI, P. (ed.) 2005. Monitoring Stream and Watershed Restoration. American Fisheries Society. Bethesda, Maryland, EUA. 350 pp.

SANTO, M. 2005. Dispositivos de passagem para peixes em Portugal. Direcçao-Geral dos Recursos Florestais. Editideias-Ediçao e Produçao, Lda. Lisboa. Portugal. 137 pp.

SOSTOA, A. (ed.). 1990. Peixos. Història Natural dels Països Catalans, 11. Enciclopèdia Catalana, SA. Barcelona. Catalonia. 487 pp.

THORNCRAFT, G. \& J. H. HARRIS. 2000. Fish Passage and Fishways in New South Wales: a Status Report. Centre for Freshwater Ecology, Canberra, Australia. 32 pp.

TRAVADE, F. \& M. LARINIER. 2002. Monitoring techniques for fishways. Bull. Fr. Pêche Piscic., 346 suppl.: $166-180$.

ZITEK, A., S. SCHMUTH \& M. JUNGWIRTH. 2008. Assessing the efficiency of connectivity measures with regard to the EU-Water Framework Directive in a Danube-tributary system. Hydrobiologia, 609: 139-161. 

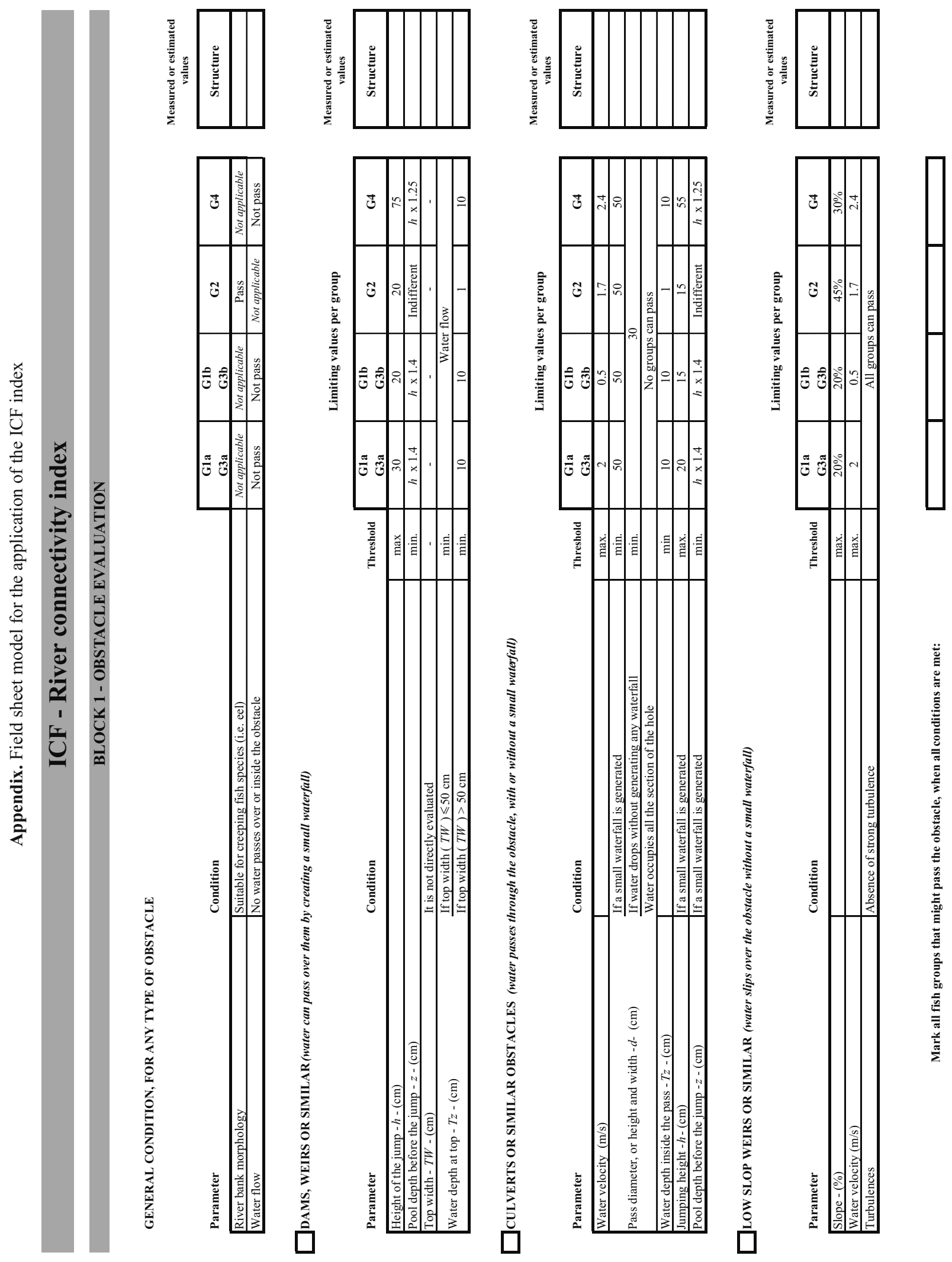

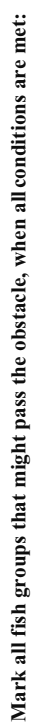




\section{ICF - River connectivity index}

\section{BLOCK 2 - FISH PASS EVALUATION}

Write the number and type of fish passes:

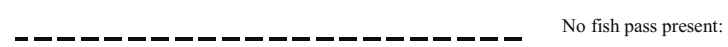

GENERAL CONDITION, FOR ANY TYPE OF FISH PASSES

\begin{tabular}{|c|c|c|c|c|c|}
\hline Parameter & Condition & $\begin{array}{l}\text { G1a } \\
\text { G3a }\end{array}$ & $\begin{array}{l}\text { G1b } \\
\text { G3b }\end{array}$ & G2 & G4 \\
\hline Exit to upstream & Obstructed or no water flow & \multicolumn{4}{|c|}{ Not pass } \\
\hline Inside the fish pass & Obstructed or no water flow & \multicolumn{4}{|c|}{ Not pass } \\
\hline
\end{tabular}

\section{BLOCK 2a - CLOSE TO NATURE FACILITIES}

$\square$ Fish ramps, bed ramps, lateral rivers or canals

\begin{tabular}{|c|c|c|c|c|c|c|}
\hline \multirow[b]{2}{*}{ Parameter } & \multirow[b]{2}{*}{ Condition } & \multirow[b]{2}{*}{ Threshold } & \multicolumn{4}{|c|}{ Limiting values per group } \\
\hline & & & $\begin{array}{l}\text { G1a } \\
\text { G3a }\end{array}$ & $\begin{array}{l}\text { G1b } \\
\text { G3b }\end{array}$ & G2 & G4 \\
\hline Slope $(\%)$ & Write the maximum present value & $\max$. & $20 \%$ & $20 \%$ & $45 \%$ & $30 \%$ \\
\hline Water velocity $(\mathrm{m} / \mathrm{s})$ & Write the maximum present value & $\max$. & 2 & 0.5 & 1.7 & 2.4 \\
\hline Water depth inside the fish pass $-z-(\mathrm{cm})$ & Write the maximum present value & $\min$. & 10 & 10 & 1 & 10 \\
\hline Pool depth before the jump -z- (cm) & If there are waterfalls & $\min$. & $h \times 1.4$ & $h \times 1.4$ & Indifferent & $h \times 1.25$ \\
\hline
\end{tabular}

BLOCK 2b - BROAD-SPECTRUM FISH PASSES

Limiting values per group

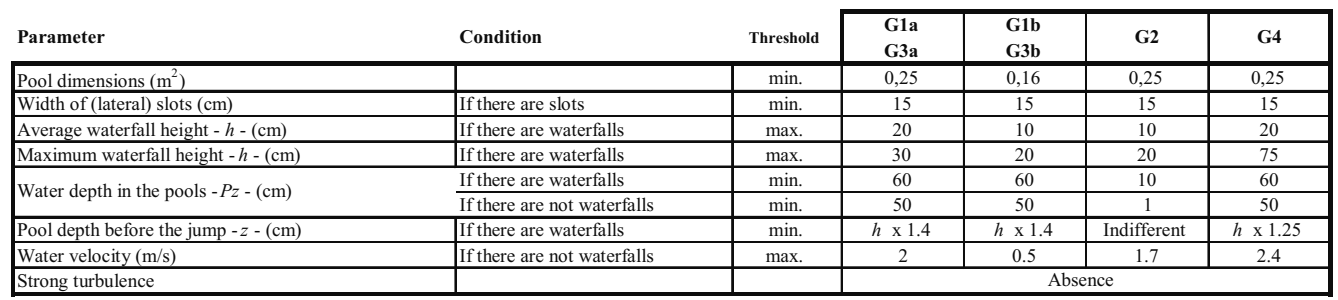

Baffle type (ramp-shaped section)

Limiting values per group

\begin{tabular}{|c|c|c|c|c|c|c|}
\hline \multirow[b]{2}{*}{ Parameter } & \multirow[b]{2}{*}{ Condition } & \multirow[b]{2}{*}{ Threshold } & \\
\hline & & & $\begin{array}{l}\text { G1a } \\
\text { G3a }\end{array}$ & $\begin{array}{l}\text { G1b } \\
\text { G3b }\end{array}$ & G2 & G4 \\
\hline Water depth $-z-(\mathrm{cm})$ & & min. & 10 & 10 & 1 & 10 \\
\hline
\end{tabular}

BLOCK 2c - TECHNICAL AND MECHANIZED OR VERY SPECIFICFISH

Gates, lifts, locks and fish pumps

Limiting values per group

\begin{tabular}{|c|c|c|c|c|c|c|}
\hline Parameter & Condition & Threshold & $\begin{array}{l}\text { G1a } \\
\text { G3a }\end{array}$ & $\begin{array}{l}\text { G1b } \\
\text { G3b }\end{array}$ & G2 & G4 \\
\hline
\end{tabular}

Measured or estimated values

Facility

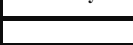

Measured or estimated

Facility

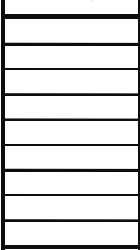

Measured or

values

Facility

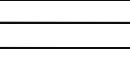

Eel ramps (or other equivalent fish passes)

Limiting values per group

\begin{tabular}{|c|c|c|c|c|c|c|}
\hline Parameter & Condition & Threshold & $\begin{array}{l}\text { G1a } \\
\text { G3a }\end{array}$ & $\begin{array}{l}\text { G1b } \\
\text { G3b }\end{array}$ & G2 & G4 \\
\hline Water velocity $(\mathrm{m} / \mathrm{s})$ & & $\max$. & Not applicable & Not applicable & 1.7 & \begin{tabular}{|l} 
Not applicable \\
\end{tabular} \\
\hline
\end{tabular}




\section{ICF - River connectivity index}

\section{BLOCK 3 - MODULATORS AND FINAL SCORE}

Mark the potentially present fish groups at the analyzed section:

\begin{tabular}{|l|l|l|l|}
\hline G1a & G1b & G2 & G4 \\
\hline
\end{tabular}

Mark the fish groups that can overcome the obstacle (block 1):

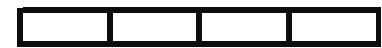

Mark the fish groups that can pass inside the fish pass (block 2):

PROVISIONAL SCORE (select one option based on the total fish groups present that can potentially overcome the obstacle and / or fish pass):

\begin{tabular}{|c|l|c|}
\hline \multirow{3}{*}{$\begin{array}{c}\text { Obstacle }+ \\
\text { Fish passes }\end{array}$} & All groups of potentially present fish can pass & $\mathbf{7 5}$ \\
\cline { 2 - 3 } & Some groups of potentially present fish can pass & $\mathbf{5 0}$ \\
\cline { 2 - 3 } & Only one group of potentially present fish can pass & $\mathbf{2 5}$ \\
\cline { 2 - 3 } & No groups of potentially present fish can pass & $\mathbf{0}$ \\
\hline
\end{tabular}

\section{MODULATORS (check only the options that meet):}

Obstacle pass through one or both sides, allowing the fish to go upstream

complements Only in low slope obstacles $(<45 \%)$, if its surface is rough and irregular

Presence of any overhanging structure at any point of the infrastructure

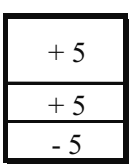

\begin{tabular}{|c|l|}
\hline \multirow{4}{*}{$\begin{array}{c}\text { Fish pass } \\
\text { complements }\end{array}$} & $\begin{array}{l}\text { Presence of a natural substrate, with similar characteristics to the one in the river, inside the fish } \\
\text { pass }\end{array}$ \\
\cline { 2 - 3 } & Correct location of the fish pass entrance (from downstream to upstream) \\
\cline { 2 - 3 } & Wrong location of the entrance (from downstream to upstream) \\
\cline { 2 - 3 } & $\begin{array}{l}\text { Width of the wet part of the fish pass below } 1 / 20 \text { average width of the river in this area } \\
\text { functionality }\end{array}$ \\
\cline { 2 - 3 } & Fish pass in a bad condition of preservation or maintenance \\
\hline
\end{tabular}

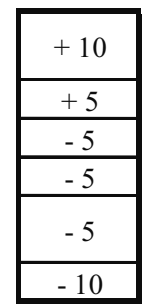

\begin{tabular}{|c|l|}
\hline \multirow{4}{*}{$\begin{array}{c}\text { Downstream } \\
\text { migration }\end{array}$} & $\begin{array}{l}\text { Fish can migrate downstream safely and directly through the obstacle (i.e., low height obstacle } \\
(<10 \mathrm{~m}) \text {, sufficient water depth, or close to nature fish pass })\end{array}$ \\
\cline { 2 - 3 } & $\begin{array}{l}\text { If there is any derivation canal, it exists some mechanisms avoiding or minimizing the entrance } \\
\text { of fish into derivation canals (mechanical, light, sound or electrical), or if there is not derivation } \\
\text { canal }\end{array}$ \\
\cline { 2 - 3 } $\begin{array}{l}\text { If there are any derivation canal, it does not exist any mechanism avoiding or minimizing the } \\
\text { entrance of fish into the derivation canal }\end{array}$ \\
\cline { 2 - 3 } $\begin{array}{l}\text { Downstream migration directly through the obstacle is possible but with risk of injury or death } \\
\text { (i.e. fall of more than } 10 \mathrm{~m})\end{array}$ \\
\hline
\end{tabular}

\begin{tabular}{|l|}
\hline+5 \\
\hline+5 \\
\hline-5 \\
\hline-5 \\
\hline
\end{tabular}

FINAL SCORE: 